\title{
Erratum to: Will Technological Change Save the World? The Rebound Effect in International Transfers of Technology
}

\author{
Mare Sarr $^{1}$. Tim Swanson ${ }^{2}$
}

Published online: 26 January 2017

(C) Springer Science+Business Media Dordrecht 2017

\section{Erratum to: Environ Resource Econ DOI 10.1007/s10640-016-0093-4}

Proposition 2 (b) contains a typographical error. It should read as follows:

(b) A reduction in $\phi$ reduces the management level $m^{\infty}\left(d m^{\infty} / d \phi>0\right)$ if $\Psi^{\prime}\left(m^{\infty}\right)>\phi\left(1-\frac{f^{\prime}\left(k^{\infty}\right)^{2}}{f\left(k^{\infty}\right) f^{\prime \prime}\left(k^{\infty}\right)}\right)$ is satisfied, and increases $m^{\infty}\left(d m^{\infty} / d \phi<0\right)$ if $\Psi^{\prime}\left(m^{\infty}\right)<\phi\left(1-\frac{f^{\prime}\left(k^{\infty}\right)^{2}}{f\left(k^{\infty}\right) f^{\prime \prime}\left(k^{\infty}\right)}\right)$ is satisfied.

The online version of the original article can be found under https://doi.org/10.1007/s10640-016-0093-4.

$凶$ Mare Sarr

mare.sarr@uct.ac.za

Tim Swanson

tim.swanson@graduateinstitute.ch

1 School of Economics, University of Cape Town, Private Bag X3, Rondebosch 7701, South Africa

2 Department of International Economics and CIES, Graduate Institute of International and Development Studies, Case Postale 136, Geneva 21 1211, Switzerland 